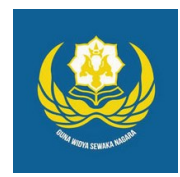

Jurnal Analogi Hukum

Journal Homepage: https://ejournal.warmadewa.ac.id/index.php/analogihukum

\title{
Disparitas Putusan Hakim dalam Tindak Pidana Narkotika
}

\author{
A.A Ngr Rai Anjasmara Putra*, I Made Sepud dan I Nyoman Sujana \\ Universitas Warmadewa, Denpasar-Bali, Indonesia \\ *anjasmara.p@gmail.com
}

How To Cite:

Putra, A, A, N, R, A., Sepud, I, M., Sujana, I, N.(2020). Disparitas Putusan Hakim dalam Tindak Pidana Narkotika. Jurnal Analogi Hukum. 2 (2). 129-135. Doi: https://doi.org/10.22225/ah.2.2.1884.129-135

\begin{abstract}
Disparity in Indonesia has a meaning of distinction, in the Science of law disparity is the difference of ruling that is dropped by judges in the same criminal act, judges in dropping the ruling often occur disparity $A$ verdict in the same case. One of them in the case of narcotics criminal act where there are perpetrators who are in prison and there are perpetrators who are in a rehabilitation ruling in this case a judge must have an understanding and view that a narcotics abuse is a victim that must be healed of a dependency disease. In the proceedings, the judges have the authority to examine and disconnect the judges in the case of a consideration which can be incriminating or alleviating the suspect in order to create justice. The purpose of this research is to know how the authority of a judge in the break of criminal acts and basic consideration of judges so that there is a disparity of verdict in narcotics criminal act. The method used is the type of normative research by conducting a statutory approach, conceptual approach and a case approach analyzed using a systematic technique with a descriptive analytical presented Assisted by the source of the collected legal materials and interpreted. Judge in a narcotics criminal offence authorized to examine the evidence tool, witness information, information defendants, and information experts and in the criminal offence break the judges are authorized to determine the defendant in the rehabilitation or sentenced to prison Proceed to basic consideration of judges in disconnecting disparity against narcotic criminal acts due to different deeds committed by the defendant where if the defendant is only a user then the decision received will be lighter and if The defendant as a distributor will give punishment
\end{abstract}

Keywords: Disparity, narcotic criminal offence, Judge's verdict

\begin{abstract}
Abstrak-Disparitas dalam bahasa indonesia memiliki arti perbedaan, dalam ilmu hukum disparitas (disparity of sentencing) yaitu perbedaan putusan yang di jatuhkan oleh hakim dalam suatu tindak pidana yang sama, Hakim dalam menjatuhkan putusan sering terjadi disparitas ini atau adanya perbedaan dalam suatu putusan dalam kasus yang sama. Salah satunya dalam kasus tindak pidana Narkotika dimana ada pelaku yang di jatuhi pidana penjara dan ada pelaku yang di jatuhi putusan rehabilitasi dalam hal ini seorang hakim haruslah memiliki pemahaman dan pandangan bahwa seorang penyalahgunaan Narkotika adalah korban yang harus di sembuhkan dari penyakit ketergantungan. Dalam proses persidangan hakim memiliki wewenang dalam memeriksa dan memutus lalu dalam memutus perkara hakim memiliki pertimbangan yang dimana bisa memberatkan ataupun meringankan tersangka agar terciptanya keadilan. Tujuan dari penelitian ini untuk mengetahui bagaimana kewenangan seorang hakim dalam memutus tindak pidana dan Dasar pertimbangan hakim sehingga terjadi disparitas putusan dalam tindak pidana Narkotika. Metode yang digunakan merupakan tipe penelitian Normatif dengan melakukan pendekatan perundang-undangan, pendekatan konseptual dan pendekatan kasus yang dianalisis menggunakan teknik bersifat sistematis dengan disajikan secara deskriptifanalitis dibantu dengan sumber bahan hukum yang dikumpulkan lalu ditafsirkan. Hakim dalam tindak pidana narkotika berwenang untuk memeriksa alat bukti, keterangan saksi, keterangan terdakwa,dan keterangan ahli dan dalam memutus tindak pidana narkotika hakim berwenang untuk menentukan terdakwa di rehabilitasi atau dipidana penjara beranjak ke Dasar pertimbangan hakim dalam memutus disparitas terhadap tindak pidana narkotika disebabkan adanya perbuatan berbeda yang dilakukan oleh terdakwa dimana jika terdakwa hanya sebagai pengguna maka putusan yang diterima akan lebih ringan dan jika terdakwa sebagai pengedar maka akan memberatkan hukumannya
\end{abstract}




\section{Pendahuluan}

Hakim merupakan organ pengadilan yang dianggap memahami hukum, yang dimana diberikan kewajiban dan tanggung jawab agar hukum berjalan dengan adil dan tidak berat sebelah/ memihak. Hakim tidak hanya berperan sebagai corong undang-undang, tetapi hakim juga berperan sebagai penemu hukum (recht vinding), sesuai dengan nilai-nilai budaya yang hidup di masyarakat, terutama nilai-nilai Pancasila (Dewi, 2014) Hakim beda dengan pejabat-pejabat lain, hakim mesti benar menguasai hukum sesuai dengan sistem yang dianut di Negara Indonesia, dalam pemeriksaan di sidang pengadilan (Waluyo, 1991).

Kedudukan Hakim merupakan kedudukan kunci keberhasilan penegakan hukum yang menjadi tujuan utama kehidupan masyarakat di Negara Hukum (Priyanto, 2005). Hakim merupakan pejabat peradilan Negara yang diberikan wewenang oleh Undang-undang untuk mengadili. Mengadili diartikan sebagai rangkaian tindakan hakim untuk menerima, memeriksa dan memutuskan perkara berdasarkan asas bebas, jujur dan tidak memihak di dalam sidang pengadilan. Dalam memberikan keadilan hakim harus menelaah terlebih dahulu tentang kebenaran peristiwa yang diajukan kepadanya kemudian memberi penilaian terhadap peristiwa tersebut dan menghubungkannya dengan hukum yang berlaku. Selepas itu hakim baru dapat menjatuhkan putusan terhadap peristiwa tersebut dan oleh sebab itu hakim dalam memberikan putusan harus berdasarkan penafsiran hukum yang sesuai dengan rasa keadilan dalam masyarakat. Terkadang polemik di dalam masyarakat timbul ketika hakim menjatuhkan pidana suatu putusan yang berbeda dalam tindak pidana yang sama (Disparitas Pidana).

Disparitas Pidana (disparity of senlencing) adalah penerapan pidana yang tidak sama dalam suatu tindak pidana yang sama, dalam hal ini hakim sering kali memberikan putusan yang beda di dalam suatu tindak pidana yang sama terutama dalam kasus tindak pidana narkotika. Dalam Undang-undang No 35 Tahun 2009 tentang tindak pidana narkotika, dimana dalam tindak pidana narkotika di bedakan menjadi dua yaitu pemakai atau pengedar. Dalam Pasal 103 Undang-undang No. 35 Tahun 2009 diatur tentang hal-hal yang membuat tersangka dapat diberikan rehabilitasi dan Pasal 129 Undangundang No 35 Tahun 2009 Tentang tindak pidana narkotika yang mengatur pidana penjara dan denda bagi pelaku tindak pidana narkotika. Hal-hal ini yang menjadi pertimbangan hakim dalam memberikan putusan.

\section{Metode Penelitian}

Penelitian hukum ini menggunakan jenis penelitian hukum normatif yaitu penelitian yang berfokus pada norma hukum positif dan dengan pendekatan masalah dalam putusan nomor 294/ Pid.Sus/2018/PN Dps dan putusan nomor 620/ Pid.Sus/2019/PN Dps dan mengacu pada peraturan perundang-undangan serta peraturan yang berkaitan dengan konseptual kasus yang diteliti yaitu Disparitas Putusan Hakim di Tindak Pidana Narkotika Penelitian ini memerlukan data sekunder sebagai data utama.

Dalam membahas tentang Disparitas Putusan Hakim dalam Tindak Pidana Narkotika menggunakan sumber bahan hukum. Sumber bahan hukum yang dipergunakan dalam penelitian ini, meliputi bahan hukum primer yaitu Undang-undang Dasar Negara Republik Indonesia tahun 1945, Undang-undang No 1 Tahun 1946 (KUHP), Undang-undang No 08 tahun 1981 Tentang Kekuasaan Kehakiman, Undang-undang Nomor 48 Tahun 2009 tentang Kekuasaan Kehakiman, Undang-undang No 35 Tahun 2009 tentang tindak pidana narkotika dan Keputusan Bersama Ketua Mahkamah Agung RI dan Ketua Komisi Yudisial RI Nomor 047/KMA/SKB/IV/2009 dan 02/SKB/ P.KY/IV/2009 tentang Kode Etik dan Pedoman Perilaku Hakim. Serta menggunakan bahan hukum sekunder yaitu Bahan hukum yang menjelaskan tentang bahan hukum primer yang didapat melalui pengkajian kepustakaan, meliputi Buku-buku, jurnal-jurnal hukum, artikel yang berhubungan dengan Disparitas Putusan Hakim dalam Memutus Tindak Pidana Narkotika. Bahan Hukum Tersier Bahan hukum yang menjadi petunjuk untuk bahan hukum sekunder yang diperoleh dari kamus hukum, kamus Bahasa, internet yang berhubungan dengan penelitian ini. Untuk memperoleh bahan -bahan hukum primer, sekunder dan tersier digunakan teknik inventarisasi atau penelusuran bahan hukum yang bersangkutan lalu di klasifikasi atau dikelompokan dan didokumentasikan, dicatat, dikutip, diringkas, diulas sesuai kebutuhan dengan pendekatan kualitatif. Menganalisis penelitian ini menggunakan teknik bersifat sistematis dengan disajikan secara deskriptif-analitis, yaitu dengan cara menganalisis dalam bentuk penelitian. Mendeskripsikan bahan hukum terlebih dahulu secara sistematis kemudian menganalisa melalui teknik analisis dengan teknik tafsiran 
dan menggunakan argumentasi yang bertumpu pada logika hukum dengan deduktif induktif.

\section{Hasil Penelitian Dan Pembahasan}

\section{Kewenangan Hakim dalam Memeriksa dan memutus Tindak Pidana Narkotika}

Hakim berwenang untuk memeriksa suatu perkara pidana khususnya disini Tindak Pidana Narkotika karena ada kekhususan di dalam Pasal 4 UU No 35 tahun 2009 yang membedakan penanganan penyalahgunaan dan pengedar, maka dari itu seorang Hakim diwajibkan untuk menggali, mengikuti agar hukum tepat sasaran. Sebagaimana sudah tercantum dalam Pasal 5 ayat (1) UU No 48 Tahun 2009 tentang kekuasaan kehakiman:

Hakim dan hakim konstitusi wajib menggali, mengikuti dan memahami nilai-nilai hukum dan rasa keadilan yang hidup dalam masyarakat.

Berdasarkan bunyi dari Pasal 5 ayat (1) tersebut dapatlah dimengerti bertujuan untuk mengatur agar supaya putusan hakim sesuai dengan hukum dan rasa keadilan dalam masyarakat. Maka untuk merealisasikannya ditetapkanlah dasar dari kewenangan hakim dalam menjalankan perannya sebagai seorang pengadil. (Hamzah, 1996)

Menggali, mengikuti serta memahami nilai dalam hukum adalah suatu hal yang mutlak harus dilakukan oleh seorang hakim dalam mengadili perkara untuk terciptanya sebuah keadilan. Dalam Pasal 153 KUHAP seorang hakim ketua diberikan wewenang memimpin pemeriksaan dalam proses persidangan dan dalam Pasal ini juga pada ayat (3) Hakim berwenang untuk keperluan proses pemeriksaan membuka sidang dan menyatakan terbuka untuk umum dalam proses persidangan Hakim berwenang untuk memeriksa alat bukti atau saksi yang di sediakan dalam persidangan. Menurut Pasal 184 ayat (1) KUHAP, alat-alat bukti ialah : (1) keterangan saksi; (2) keterangan ahli; (3) surat ;(4) petunjuk; dan (5) keterangan terdakwa.

Dari putusan Nomor 294/Pid.Sus/2018/PN Dps Hakim berwenang untuk memeriksa keterangan saksi-saksi dan bukti-bukti yang diajukan oleh penuntut umum untuk membuktikan dakwaan yang diajukan dimana sebagi pokoknya sebagai berikut:

Menyatakan Terdakwa I GUSTI NGURAH HARI PAWITRA, ST Als. ARI telah terbukti secara sah dan meyakinkan bersalah melakukan tindak pidana Narkotika yaitu "Menggunakan narkotika golongan I bagi dirinya sendiri“, sebagaimana diatur dan diancam pidana dalam Pasal 127 ayat (1) huruf a UU RI No. 35 Tahun 2009 tentang narkotika, dalam Dakwaan Alternatif Kedua ;

Menjatuhkan pidana terhadap Terdakwa I GUSTI NGURAH HARI PAWITRA, ST Als. ARI dengan pidana penjara selama 1 (satu) tahun dan 4 (empat) bulan dikurangi selama terdakwa berada dalam tahanan ;

\section{Menyatakan barang bukti berupa :}

(satu) buah plastik klip bening yang dalamnya berisi 1 (satu) butir tablet warna merah muda berlogo supermen yang diduga mengandung sediaan Narkotika Jenis Ekstasy dengan berat 0,28 gram netto.

\section{(satu) potong celana Jean warna biru,}

(satu) buah HP wana putih kasing merah Merk Oppo Type F5 dengan Sim card 087862358605 .

1 (satu) buah HP warna Gold merek Samsung Type J7 dengan sim card 081353071115.

\section{Dirampas untuk dimusnahkan;}

Menetapkan biaya perkara sebesar Rp.2.000,- (dua ribu rupiah) dibebankan kepada terdakwa;

Hakim juga berwenang memeriksa keterangan dari terdakwa, dimana terdakwa menyatakan:

Bahwa terdakwa ditangkap dan digeledah oleh petugas Kepolisian dari Kantor Direktorat Reserse Narkoba Polda Bali, pada hari minggu, tanggal 21 januari 2018, pukul 03.30 Wita, bertempat di Halaman depan pertokoan Gunung Soputan Blok B Jalan Gunung Soputan No. 11 Denpasar Barat Br. Abian timbul Desa Pemecutan Kelod Kec. Denpasar Barat Kota Denpasar Bali;

Bahwa saat dilakukan penangkapan dan penggeledahan terhadap diri terdakwa ditemukan barang berupa 1 (satu) buah plastik klip bening yang dalamnya berisi 1 (satu) butir tablet warna merah muda berlogo supermen yang diduga mengandung sediaan narkotika jenis Ekstasy dengan berat 0,28 gram netto yang ditemukan pada saku kecil sebelah kanan celana jean warna biru yang terdakwa gunakan;

Bahwa Terdakwa sendiri yang memiliki, menyimpan dan menguasai barang berupa 
Narkotika jenis ekstasy tersebut yang ditemukan pada diri terdakwa;

Bahwa Terdakwa menggunakan narkotika jenis Ekstasy sejak 6 (enam) bulan yang lalu dan terdakwa menggunakan barang berupa Narkotika jenis ekstasy tidak konstan kadang terdakwa pernah menggunakan barang berupa Narkotika jenis ekstasy seminggu dua kali;

Bahwa terdakwa membeli barang berupa Narkotika jenis ekstasy dengan harga Rp. 400.000 (empat ratus ribu rupiah) dari saudara DONI dan tersangka memesan barang tersebut dengan cara awalnya terdakwa dihubungi oleh saudara DONI via telpon dan menawarkan barang berupa ekstasy kemudian terdakwa melakukan pembelian dan terdakwa membeli Narkotika sebanyak 3 (tiga) kali dari saudara DONI;

Bahwa setelah menggunakan/ mengonsumsi Ekstasy pikiran terasa rilek dan lupa sesaat ketika ada beban pikiran ataupun permasalahan;

Bahwa terdakwa tahu hal itu dilarang di Wilayah Indonesia dan terdakwa mengaku bersalah serta merasa menyesal;

Bahwa terdakwa tidak memiliki ijin dari pihak berwenang untuk barang berupa Narkotika jenis Ekstasy;

Dan untuk menguatkan keputusannya di dalam kasus Tindak Pidana Narkotika Hakim berwenang untuk memeriksa keterangan ahli yang disini berupa berita acara pemeriksaan laboratoris Kriminalistik No. Lab. 83/ NNF/2018, tanggal 24 Januari 2018, yang pada kesimpulannya menerangkan bahwa barang bukti dengan nomor 309/201/NF, berupa pecahan tablet warna merah muda 310/2018/NF berupa cairan warna kuning/urine dan 311/2018/NF berupa cairan darah seperti tersebut dalam I adalah benar mengandung sediaan narkotika MDMA dan terdaftar dalam golongan I (satu) nomor urut 37 Lampiran 1 Undang-Undang Republik Indonesia No. 35 Tahun 2009 tentang narkotika; dalam memutus tindak pidana narkotika hakim berwenang Dalam membuat suatu keputusan, hakim pada dasarnya sudah di berikan kebebasan untuk dapat memutus tanpa adanya intervensi dari pihak manapun hal ini di tegaskan dalam Pasal 3 UU No 48 tahun 2009 Tentang Kekuasaan Kehakiman. Hal itu dikarenakan suatu putusan hakim adalah cerminan dari penegakan hukum dan keadilan.

Dalam kasus tindak pidana narkotika ada perbedaan sanksi yang di jatuhkan seorang hakim pada seorang pengedar narkotika dan pengguna, ada beberapa sanksi dalam UU Narkotika antara lain:

Hukuman penjara dan/ atau denda bagi terdakwa yang terbukti sebagai pengedar

Dan berupa rehabilitasi bagi terdakwa yang terbukti sebagai penyalah guna/ pemakai untuk dirinya sendiri

Untuk upaya rehabilitasi, seorang Hakim memiliki wewenang untuk memutuskan berdasarkan Pasal 103 UU No. 35 Tahun 2009, antara lain:

Hakim yang memeriksa perkara Pecandu Narkotika dapat:

memutus untuk memerintahkan yang bersangkutan menjalani pengobatan dan/ atau perawatan melalui rehabilitasi jika Pecandu Narkotika tersebut terbukti bersalah melakukan tindak pidana Narkotika; atau

menetapkan untuk memerintahkan yang bersangkutan menjalani pengobatan dan/ atau perawatan melalui rehabilitasi jika Pecandu Narkotika tersebut tidak terbukti bersalah melakukan tindak pidana Narkotika.

Masa menjalani pengobatan dan/atau
perawatan bagi Pecandu
sebagaimana dimaksud pada ayat (1) huruf a
diperhitungkan sebagai masa menjalani
hukuman.

Di kasus Tindak Pidana Narkotika segala ketentuan pidana diatur dalam UU nomor 35 Tahun 2009 tentang Narkotika. Dalam memutus suatu perkara pidana hakim mesti berlandaskan pada peraturan yang dimana mengatur perbuatan tindak pidana yang dilakukan oleh terdakwa. Tentang sebuah perkara penyalahgunaan Narkotika dan putusan yang akan dijatuhkan kepada terdakwa, dalam pasal 129 Undang-undang No 35 Tahun 2009 Tentang Narkotika telah di atur tentang hukuman pidana untuk pelaku tindak pidana narkotika yaitu: pidana penjara paling singkat 4 tahun dan paling lama tahun dan denda paling banyak Rp5.000.000.000,00 (lima miliar rupiah)

Berdasarkan ketentuan dalam pasal ini hakim akan menggunakannya sebagai pedoman dalam memutus tindak pidana narkotika, namun tetap hakim bebas untuk menetapkan berat ringannya suatu pidana yang dijatuhkannya berdasarkan pertimbangan-pertimbangan yang ada.

Berdasarkan UU ini jelas hakimlah yang 
berwenang untuk memutus dapat tidaknya pelaku penyalahgunaan narkotika di berikan rehabilitasi.

Menurut (Sujono \& Daniel, 2011) Pemberian kewenangan kepada hakim untuk dapat memberikan rehabilitasi bagi para pecandu Narkotika merupakan hal yang patut diapresiasi karena menempatkan seorang pecandu sebagai korban bukan sebagai pelaku tindak kriminal. Sebagaimana selama ini pecandu narkotika yang di tempatkan sebagai pelaku kriminal kehilangan hak-haknya sebagai korban untuk mendapatkan pemulihan.

\section{Dasar Pertimbangan Hakim Dalam Memutus Tindak Pidana Narkotika}

Kasus penyalahgunaan Narkotika bukan hal yang luar biasa lagi di indonesia, banyak pelaku tindak pidana yang sudah menjalankan hukuman namun tertangkap lagi. (Yamin, 2012) Menurut Jahid Hanafi alasannya yaitu tidak bisa keluar dari ketergantungan pada Narkotika dan kembali menyalah gunakan Narkotika. Sehingga sanksi dengan pidana penjara tidaklah begitu efektif untuk membuatjera pecandu Narkotika dan Oleh karena itu, Rehabilitasi dianggap sebagai pemidanaan yang lebih tepat untuk menanggulangi penyalahgunaan Narkotika. (Hanafi, 2013)

Hal mengenai Rehabilitasi untuk terdakwa tindak pidana penyalahgunaan Narkotika telah ada dalam pasal 54, 55, dan 103 dalam Undangundang No 35 Tahun 2009 Tentang Narkotika, Pelaksanaan Rehabilitasi bagi penyalahgunaan Narkotika sangat penting dilakukan karena itu adalah sebuah upaya penyembuhan yang dilalukan dengan ilmu kesehatan. Sebagaimana diketahui Narkotika merupakan jenis obat yang mana jika dikonsumsi terus menerus akan membawa akibat kecanduan. (Yamin, 2012) Hal ini yang mendasari dilakukannya tindakan Rehabilitasi agar penyalahgunaan lepas dari jeratan Narkotika. Dalam mempertimbangkan tindakan untuk pelaku penyalahgunaan Narkotika haruslah memiliki surat keterangan dari seorang ahli untuk membuktikan bahwa pelaku penyalahgunaan Narkotika tersebut adalah pecandu.

\section{Menggunakan Putusan Nomor 294/ Pid.Sus/2018/PN Dps}

Pada putusannya Majelis Hakim pada pengadilan Negeri Denpasar memuat amar sebagai berikut:

Menyatakan Terdakwa, I Gusti Ngurah Hari Pawitra, ST atau yang disebut Ari sudah terbukti secara sah dan meyakinkan telah salah melakukan tindak pidana penyalahgunaan Narkotika golongan I bagi diri sendiri;

Menjatuhkan pidana kepada Terdakwa oleh sebab itu dengan pidana penjara selama : 1 (satu) tahun;

Menetapkan, lamanya Terdakwa ada dalam tahanan dikurangi seluruhnya dengan pidana yang dijatuhkan;

Menetapkan Terdakwa untuk menjalani Rehabilitasi Medis dan Sosial di Panti Rehabilitasi Yayasan ANARGYA, jalan Kerta Dalem VII No. 6 Sidakarya Denpasar Selatan;

Menetapkan masa menjalani Rehabilitasi Medis dan Sosial tersebut diperhitungkan sebagai masa menjalani pidana;

Memerintahkan agar Terdakwa dikeluarkan dari Rumah Tahanan Negara (RUTAN);

\section{Menetapkan barang bukti berupa :}

1 (satu) buah plastik klip bening yang dalamnya berisi 1 (satu) butir tablet warna merah muda berlogo supermen yang diduga mengandun gsediaan Narkotika Jenis Ekstasy dengan berat 0,28 gram netto.

\section{1 (satu) potong celana Jean warna biru,}

1 (satu) buah HP wana putih kasing merah Merk Oppo Type F5 dengan Sim card 087862358605.

1 (satu) buah HP warna Gold merek Samsung Type J7 dengan sim card081353071115.Dirampas untuk dimusnahkan;

Membebankan kepada Terdakwa untuk membayar biaya perkara sebesar Rp. 2.000,(dua ribu rupiah);

Hal yang meringankan Terdakwa :

Terdakwa mengaku bersalah dan menyesali perbuatannya;

Terdakwa bersikap sopan dan berjanji tidak mengulangi lagi perbuatannya;

Terdakwa belum pernah dihukum

Didalam UU No 35 tahun 2009 tentang Narkotika sudah dijelaskan prihal siapa-siapa saja yang bisa disebut sebagai pengedar, dan dijelaskan sebagai berikut:

Pengedar Narkotika, diberi beberapa penyebutan sesuai perannya masing-masing, 
yaitu:

Pihak yang membuat Narkotika melawan hukum (Pasal 1 angka 3 jo Pasal 113);

Pihak yang mengedarkan keluar Narkotika secara Melawan Hukum (Pasal 1 angka 4 jo Pasal 113);

Pihak yang menjual keluar Narkotika secara melawan hukum (Pasal 1 angka 5 jo Pasal 113);

Pihak yang melakukan Pengangkutan atau Transito Narkotika secara melawan hukum (Pasal 1 angka 9, 12 jo Pasal 115);

Pihak yang melaksanakan Peredaran Gelap Narkotika dan Preskusor Narkotika (Pasal 1 angka 6 jo 111,112, 129).

Pengguna Narkotika, juga diberi beberapa penyebutan, yaitu:

Pecandu Narkotika (Pasal 1 angka 13 jo Pasal 54 jo Pasal 127);

Penyalah guna Narkotika (Pasal 1 angka 15 jo Pasal 54 jo Pasal 127).

Seperti yang telah dipaparkan diatas, tentang golongan atau jenis-jenis dan klasifikasi peran pihak yang bersangkutan dengan narkotika, maka, dalam UU ini sudah diatur juga prihal sanksi-sanksi pidana bagi pihak yang melanggar ketentuan seperti diatas. Bagi pihak yang membuat, mengedarkan/ menjual atau pihak yang sebagai penyambung pastinya sanksi hukumnya jauh sangat berat daripada pihak yang hanya menggunakan saja. Namun pada klasifikasi pengedarpun dibagi lagi sesuai perannya, apakah hanya sebatas penjual/ kurir atau sebagai yang memproduksi/ bandar besar.

\section{Menggunakan Putusan Nomor 620/ Pid.Sus/2019/PN Dps}

Pada putusannya Majelis Hakim pada pengadilan Negeri Denpasar memuat amar sebagai berikut:

Menyatakan Terdakwa MOH. ABDUL MUNTOLIB dan Terdakwa RISKA ANASTASIA tersebut di atas, terbukti secara sah dan meyakinkan bersalah melakukan tindak pidana menguasai Narkotika Golongan I bukan tanaman melebihi 5 (lima) gram, sesuai didalam dakwaan alternatif pertama Penuntut Umum;

Menjatuhkan pidana kepada Terdakwa oleh karena itu dengan pidana penjara masingmasing selama 10 (sepuluh) tahun, pidana denda sebesar Rp.1.000.000.000,00 (satu milyar rupiah);

Menetapkan jika pidana denda itu tidak dibayar oleh Terdakwa maka harus diganti dengan pidana penjara selama 3 (tiga) bulan;

Menetapkan masa penangkapan dan penahanan yang telah dijalani Terdakwa dikurangkan seluruhnya dari pidana yang dijatuhkan;

Menetapkan Terdakwa tetap ditahan;

Menetapkan barang bukti berupa:

1 (satu) unit Sepeda motor Honda Beat Warna Putih No. Pol. : DK-3588-QH beserta STNK dan Kunci kontak;

1 (satu) buah buku tabungan Bank BNI No. Rekening :0734192721, atas nama RISKA ANASTASIA. Dikembalikan kepada terdakwa RISKA ANASTASIA.

barang berupa 28 (dua puluh delapan) paket plastik klip berisi kristal bening sabu setelah dilakukan penimbangan diperoleh berat bersih total seberat 20,33 gram dan 2 (dua) paket plastik klip berisi masing-masing 5 (lima) butir ekstasi setelah dilakukan penimbangan diperoleh berat bersih total seberat 4,06 gram.

Membebankan kepada Terdakwa untuk membayar biaya perkara ini masing-masing sejumlah Rp. 2.000,- (dua ribu rupiah);

Prihal memberatkan Terdakwa :

Perbuatan Terdakwa mengganggu masyarakat;

Perbuatan Terdakwa tidak mendukung program pemerintah dalam pemberantasan narkotika dan dapat merusak moral dan mental generasi muda;

Dari dua putusan diatas dapat dikatakan terjadinya sebuah disparitas putusan oleh hakim berdasarkan perbuatan yang dilakukan oleh terdakwa dimana pada kasus tindak pidana narkotika pertama terdakwa adalah seorang penyalahgunaan Narkotika yang dapat diputuskan untuk menjalani rehabilitasi sedangkan pada kasus tindak pidana yang kedua terdakwa membantu untuk mengedarkan Narkotika dalam hal ini terdakwa dijatuhi hukuman pidana penjara selama 10 tahun dan denda sebesar Rp.1.000.000.000,00 maka atas dasar inilah disparitas putusan hakim dalam tindak pidana Narkotika bisa terjadi .

\section{Simpulan}

Berdasarkan uraian dalam pembahasan, 
dapat dibuat simpulan, sebagai berikut:

kewenangan hakim dalam memeriksa dan memutus Tindak Pidana Narkotika adalah: memeriksa keterangan saksi-saksi dan buktibukti yang diajukan oleh penuntut umum, Hakim juga berwenang untuk memeriksa keterangan dari terdakwa dan untuk menguatkan putusannya di dalam kasus Tindak Pidana Narkotika hakim berwenang untuk memeriksa keterangan ahli berupa berita acara pemeriksaan laboratoris Kriminalistik yang berupa hasil urine/ darah dan hakim memiliki wewenang untuk memutus terdakwa sebagai pengguna narkotika berdasarkan Pasal 103 Undang-undang No. 35 Tahun 2009 serta memutus terdakwa sebagai pengedar berdasarkan Pasal 129 Undang-undang No. 35 Tahun 2009.

Dasar pertimbangan hakim dalam memutus disparitas terhadap tindak pidana narkotika disebabkan adanya perbuatan berbeda yang dilakukan oleh terdakwa dimana jika terdakwa hanya merupakan seorang pengguna maka putusan yang diterima dapatlah diringankan dengan menjalankan rehabilitasi dan pertimbangan yang memberatkan adalah dimana terdakwa mengedarkan/ menjual Narkotika kepada masyarakat dan dapat dikenakan sanksi berupa kurungan Penjara dan denda. Berdasarkan kasus diatas dapat disimpulkan dasar pertimbangan hakim dalam menjatuhkan putusan disparitas disebabkan adanya perbuatan berbeda yang dilakukan oleh terdakwa meskipun dalam tindak pidana yang sama yaitu Narkotika.

\section{DAFTAR PUSTAKA}

Dewi, E. (2014). Peranan Hakim Dalam Penegakan Hukum Pidana Indonesia. Jurnal Kompilasi, 1. Retrieved from https://jurnal.fh.unila.ac.id/index.php/ kompilasi/article/view/234

Hamzah, A. (1996). KUHP dan KUHAP. Jakarta: Rineka Cipta.

Hanafi, J. (2013). Pertimbangan Hakim Dalam Menjatuhkan Putusan Tindak Pidana Pecandu Narkotika. Universitas Islam Negeri Kalijaga.

Priyanto, A. (2005). Citra hakim dan penegakan hukum dalam sistem peradilan pidana di Indonesia Anang Priyanto. Jurnal Civics Media Kajian Kewarganegaraan, 2(2). Retrieved from https://journal.uny.ac.id/ index.php/civics/article/view/4374
Sujono, A. R., \& Daniel, B. (2011). Komentar dan Pembahasan Tentang UndangUndang No 35 tahun 2009 Tentang Narkotika. Jakarta: Sinar Grafika.

Waluyo, B. (1991). Implementasi Kekuasaan Kehakiman Republik Indonesia. Jakarta: Sinar Grafika.

Yamin, M. (2012). Tindak Pidana Khusus. Bandung: Pustaka Setia. 